\title{
Toddler foods and milks don't stack up against regular foods and milks
}

\author{
Jennifer McCann ${ }^{1 *}$ (D) Kelsey Beckford ${ }^{2}$, Holly Beswick ${ }^{3}$, Melanie Chisholm ${ }^{4}$ and Julie Woods ${ }^{5}$
}

\begin{abstract}
Aim: To compare the cost and nutritional profiles of toddler-specific foods and milks to 'regular' foods and milks.

Methods: Cross-sectional audit of non-toddler specific ('regular') foods and milks and secondary analysis of existing audit data of toddler specific (12-36 months) foods and milks in Australia.

Main findings: The cost of all toddler-specific foods and milks was higher than the regular non-toddler foods. Foods varied in nutritional content, but toddler foods were mostly of poorer nutritional profile than regular foods. Fresh milk cost, on average, $\$ 0.22$ less per $100 \mathrm{~mL}$ than toddler milk. Toddler milks had higher mean sugar and carbohydrate levels and lower mean protein, fat, saturated fat, sodium and calcium levels per $100 \mathrm{~mL}$, when compared to fresh full fat cow's milk.

Conclusions: Toddler specific foods and milks cost more and do not represent value for money or good nutrition for young children.

Keywords: Toddler, Public health, Nutrition, Cost
\end{abstract}

\section{Background}

Late infancy and early toddlerhood are key times for young children to be exposed to a variety of food textures, flavours and tastes [1-3]. Children are pre-disposed to have a preference for sweet and salty tastes, reject sour and bitter flavours, and reject new foods [4, 5]. Young children learn to eat what is provided through flavour and texture familiarisation [4], and if unhealthy eating habits are formed in the early years, they are likely to take these into adulthood and be at greater risk of diet related chronic diseases $[6,7]$.

A major shift in the global food system has occurred with ultra-processed foods (UPF) becoming the main source of energy in both adults and children [8-13], in a typical western diet. This is a key driver of the obesity epidemic worldwide [14]. Global research indicates that

\footnotetext{
*Correspondence: j.mccann@deakin.edu.au

${ }^{1}$ Institute for Physical Activity and Nutrition (IPAN), School of Exercise and Nutrition Sciences, Deakin University, Geelong, Australia

Full list of author information is available at the end of the article
}

toddlers are becoming regular consumers of commercially available foods and milks $[15,16]$. An Australian study found that discretionary foods contributed just over $10 \%$ of total energy intake in toddlers [15], and packaged infant and toddler snack foods made up $9 \%$ of this total. Toddler milk consumption is also on the rise, with Australian research demonstrating close to $40 \%$ of toddlers are consuming toddler milks [16], and this is predicted to continue to rise $[9,17]$. In addition, research has shown that the largely unregulated retail market for toddler foods and milks is increasing at unprecedented rates around the globe $[9,18]$.

Despite Australian research demonstrating that a healthy diet (low in UPF and drinks) costs less than an unhealthy diet (high in UPF and drinks) [19], convenience [20], on-pack marketing [21-23] traditional marketing such as television, radio and print [24, 25], as well as social media [26] are strongly influencing consumers to choose unhealthy diet patterns (typically high in UPF and drinks) [27]. As family lives become busier, consumer demand for convenience is strong, despite the cost $[20$, 
$28,29]$. Planning a healthy diet takes time [20] which is in short supply for many families, and they may compromise health for convenience to fit busy lifestyles [28, 30]. Food cost is an important determinant of food intake and of food security, with those in lower socioeconomic positions more likely to experience food insecurity [31] and have dietary patterns that are generally lower in the basic healthy foods such as fresh fruit and veg and higher in discretionary, UP foods [32]. Dietary intake studies from the US have reported that up to $8 \%$ of total dietary intake for toddlers in low-income households comes from added sugars, compared to $2 \%$ in higher income households, and the excess sugar, sodium, saturated fat in toddlers' diets is mostly from commercial foods and drinks [33].

As many toddler specific foods and milks are promoted on pack as being healthy, better than homemade, and even necessary, and being mindful of nutrition equity issues with food costs, an analysis was conducted to compare the cost and nutritional profiles of toddler specific foods and milks to non-toddler foods and milks.

\section{Methods}

Using the online shopping sites of Coles and Woolworths (representing approximately $70 \%$ of the market share of all grocery sales in Australia) [34], a search was conducted in September 2020 to collect data on the cost and nutrition of 'regular' foods and milks (full fat milks, cereal/fruit bars, dried and fresh fruit, raw ingredient balls, rice crackers and yoghurts, across a range of cost values representing the least expensive, regular price brands and premium brands). These were compared to all category specific, equivalent toddler foods and milks (marketed towards children aged 12-36 months) identified and included in a 2019 Australian audit [35]. Prices of the toddler foods and milks were checked in 2020 and updated if required if they differed from the 2019 audit results. Data pertaining to the country of origin, unit price, unit size (g), suggested serving size and number of serves per pack were collected from the product images and descriptions, and price per serve was calculated. Nutrient content per serve was determined using the nutrition information panel. Nutrients assessed were energy $(\mathrm{kJ})$, protein $(\mathrm{g})$, fat $(\mathrm{g})$, saturated fat $(\mathrm{g})$, carbohydrates (g), total sugars (g), sodium (mg) (and calcium (mg)) for milk, yoghurts, and toddler milks and yoghurts only. Mean cost and nutrient values were calculated for each product category including within categories where regular and premium type products were identified, and subsequent comparisons were then made between the 'regular' foods and milks and the toddler specific foods and milks. Regular full fat milks $(n=2)$ were compared with regular toddler milks $(n=8)$, as well as with premium toddler milks $(n=12)$. Premium full fat milks (includes branded (non-home brand) and A2 milks, $n=9)$ were compared with premium toddler milks $(n=12)$, and premium and organic full fat milks $(n=13)$ were compared to premium, A2 and organic toddler milks $(n=18)$.

\section{Results}

There were 88 toddler-specific foods and 26 toddler milks included for comparison to 49 'regular' foods and 15 milks. The majority of toddler snacks (64\%) and milks (82\%) were manufactured in Australia and New Zealand, with $28 \%$ of snacks and $15 \%$ of milks imported from Europe and small percentages from Asia and the USA.

Overall, all fresh 'regular' milk varieties cost less than their toddler milk counterparts per $100 \mathrm{~mL}$ (Tables 1 and 2). Serve sizes for all 'regular' foods were larger than serve sizes for toddler-specific snack foods, thus the analysis for comparisons were conducted using per $100 \mathrm{~g} / \mathrm{mL}$ for consistency. Whilst serve sizes for toddler milks were lower than for 'regular' milks, when based on an average toddler milk serve size of $200 \mathrm{~mL}$, there is a cost difference of 44 cents per serve. If one $(200 \mathrm{~mL})$ serving of toddler milk was consumed every day for 1 month instead of consuming one serve of full fat cow's milk, the cost difference would be on average $\$ 13$ over 1 month and close to $\$ 160$ a year. This is based on the combined mean price of all toddler milks, with premium milks costing more, and regular toddler milks (non-premium) costing less, with a range of $\$ 8-\$ 17 /$ month, equating to $\$ 100-\$ 208 /$ year. Furthermore, the fresh milks had higher mean protein, fat, saturated fat, and sodium levels and lower mean carbohydrate and total sugar levels per $100 \mathrm{~mL}$, when compared to toddler milks. Some toddler milks had $8 \mathrm{~g}$ more sugar per $200 \mathrm{~mL}$ serve than fresh full fat milks, equating to 60 teaspoons per month, or close to $3 \mathrm{~kg}$ of sugar per year if one serve was consumed daily when compared to fresh full milk. The mean calcium levels varied across toddler milks, but the mean calcium level of all toddler milks was lower than the mean levels in all fresh full fat milks. The premium stage 4 and premium organic toddler milks had significantly higher mean calcium levels per $100 \mathrm{~mL}$ than any other toddler milks or fresh full fat milks.

When comparing the toddler-specific snacks and yoghurts (labelled for within the age range of 12-36 months) to similar 'regular' products on the market, fruit-based snacks had a higher mean total sugar compared to regular fresh fruit per $100 \mathrm{~g}$ ( $40 \mathrm{~g}$ and $9.2 \mathrm{~g}$ respectively) and the fresh fruit had lower mean values for all nutrients on the nutrition information panel when compared to the toddler-specific fruit sweetened snacks per $100 \mathrm{~g}$. 'Regular' rice-based snacks had lower mean total and saturated fat and total sugar per $100 \mathrm{~g}$, compared to the toddler-specific varieties, in 


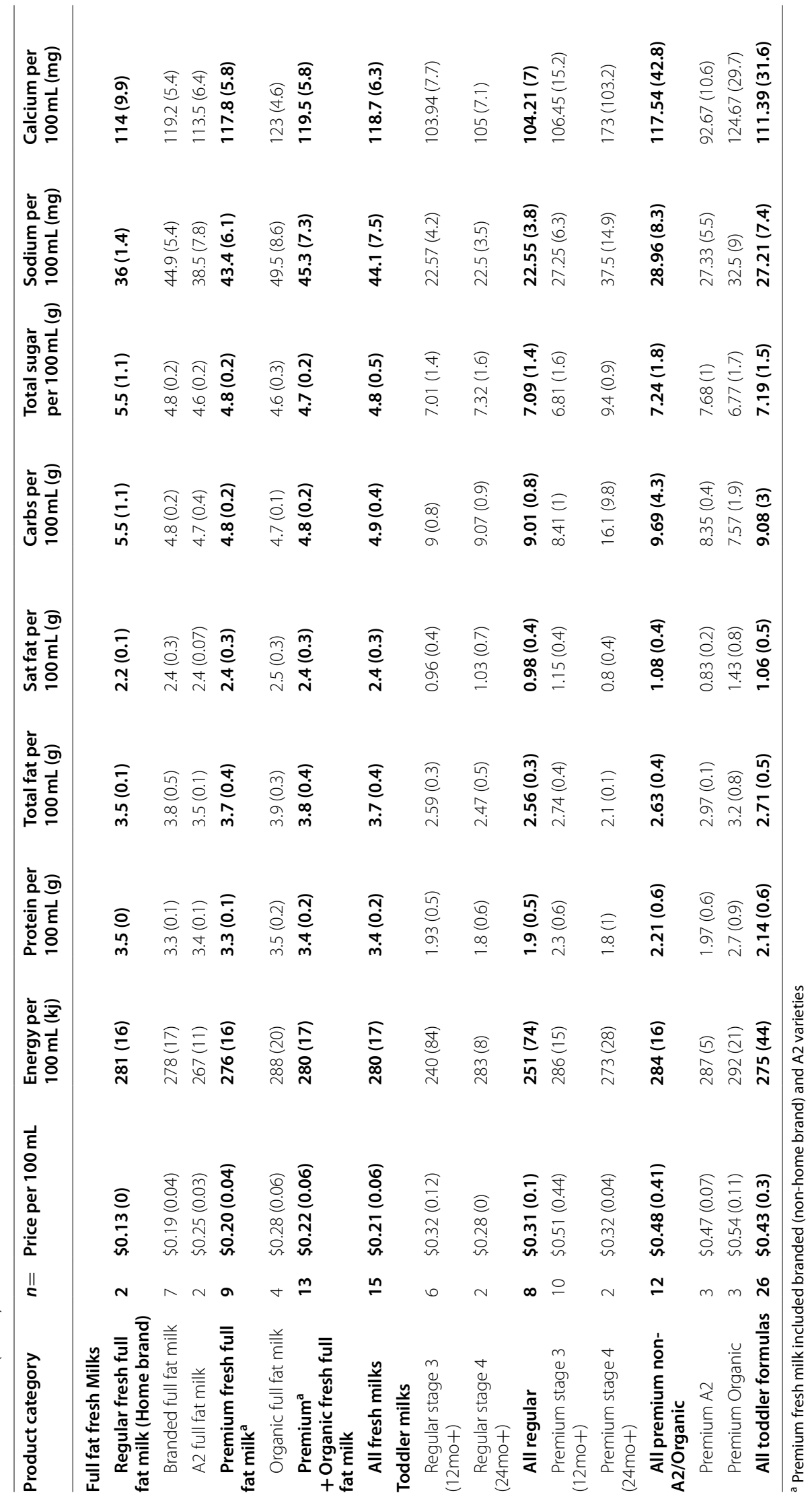


Table 2 Difference in cost and nutrition of toddler foods and milks to'regular' foods and milks

\begin{tabular}{|c|c|c|c|c|c|c|c|c|c|}
\hline & $\begin{array}{l}\text { Price per } \\
100 \mathrm{~mL} / \mathrm{g}\end{array}$ & $\begin{array}{l}\text { Energy per } \\
100 \mathrm{ml} / \mathrm{g}(\mathrm{kJ})\end{array}$ & $\begin{array}{l}\text { Protein per } \\
100 \mathrm{~mL} / \mathrm{g}(\mathrm{g})\end{array}$ & $\begin{array}{l}\text { Total fat per } \\
100 \mathrm{~mL} / \mathrm{g}(\mathrm{g})\end{array}$ & $\begin{array}{l}\text { Sat Fat per } \\
100 \mathrm{~mL} / \mathrm{g}(\mathrm{g})\end{array}$ & $\begin{array}{l}\text { Carbohydrate } \\
\text { per } 100 \mathrm{~mL} / \mathrm{g} \\
\text { (g) }\end{array}$ & $\begin{array}{l}\text { Total Sugar } \\
\text { per } 100 \mathrm{~mL} / \mathrm{g} \\
\text { (g) }\end{array}$ & $\begin{array}{l}\text { Sodium per } \\
100 \mathrm{~mL} / \mathrm{g} \\
(\mathrm{mg})\end{array}$ & $\begin{array}{l}\text { Calcium per } \\
100 \mathrm{~mL} / \mathrm{g} \\
(\mathrm{mg})\end{array}$ \\
\hline $\begin{array}{l}\text { Regular fresh } \\
\text { full fat milk vs } \\
\text { regular tod- } \\
\text { dler milk }\end{array}$ & $\$ 0.14^{b}$ & 28.01 & 1.46 & 1.13 & 1.39 & $4.05^{b}$ & $2.12^{b}$ & 20.34 & 13.67 \\
\hline $\begin{array}{l}\text { Regular fresh } \\
\text { full fat milk } \\
\text { vs premium } \\
\text { toddler milk }\end{array}$ & $\$ 0.31^{b}$ & $5.21^{b}$ & 1.14 & 1.06 & 1.28 & $4.72^{b}$ & $2.27^{b}$ & 13.93 & 0.33 \\
\hline $\begin{array}{l}\text { Premium } \\
\text { fresh full fat } \\
\text { milk vs pre- } \\
\text { mium toddler } \\
\text { milk }\end{array}$ & $\$ 0.29^{b}$ & $5.67^{b}$ & 1.10 & 1.13 & 1.33 & $4.87^{b}$ & $2.42^{b}$ & 15.90 & 1.62 \\
\hline $\begin{array}{l}\text { Premium \& } \\
\text { organic fresh } \\
\text { full fat milk } \\
\text { vs premium \& } \\
\text { organic tod- } \\
\text { dler milk }\end{array}$ & $\$ 0.08$ & $6.36^{b}$ & 1.13 & 0.96 & 1.32 & $4.35^{b}$ & $2.52^{b}$ & 16.03 & 4.91 \\
\hline $\begin{array}{l}\text { All milk vs all } \\
\text { formula }\end{array}$ & $\$ 0.22^{b}$ & 4.55 & 1.26 & 1.0 & 1.33 & $4.22^{b}$ & $2.37^{b}$ & 16.86 & 7.32 \\
\hline $\begin{array}{l}\text { Cereal/fruit } \\
\text { bars vs Tod- } \\
\text { dler cereal/ } \\
\text { fruit bars }\end{array}$ & $\$ 2.21^{b}$ & 113.93 & $0.08^{b}$ & 2.23 & 2.24 & 2.14 & 2.98 & $74.59^{b}$ & \\
\hline $\begin{array}{l}\text { Dried fruit vs } \\
\text { Dried fruit } \\
\text { snacks }\end{array}$ & $\$ 9.94^{\mathrm{b}}$ & $132.97^{b}$ & $0.12^{b}$ & 0.45 & 0.09 & $7.22^{b}$ & $0.72^{b}$ & 48.09 & \\
\hline $\begin{array}{l}\text { Fresh fruit vs } \\
\text { Fruit based } \\
\text { snacks }^{\mathrm{a}}\end{array}$ & $\$ 11.38^{b}$ & $799.76^{b}$ & $3.20^{\mathrm{b}}$ & $2.69^{b}$ & $0.59^{b}$ & $38.66^{b}$ & $31.46^{b}$ & $34.93^{b}$ & \\
\hline $\begin{array}{l}\text { Organic/Raw } \\
\text { balls/bites vs } \\
\text { Raw/organic } \\
\text { snacks }\end{array}$ & $\$ 0.69^{b}$ & 49.50 & 4.79 & $0.59^{b}$ & $6.53^{b}$ & $2.60^{b}$ & $4.85^{b}$ & 10.55 & \\
\hline $\begin{array}{l}\text { Rice crackers } \\
\text { vs Rice based } \\
\text { snacks }\end{array}$ & $\$ 8.32^{\mathrm{b}}$ & $63.85^{b}$ & 0.86 & $3.23^{b}$ & $1.19^{b}$ & 3.59 & $3.24^{b}$ & 211.34 & \\
\hline $\begin{array}{l}\text { Yoghurt } \\
\text { vs Toddler } \\
\text { yoghurts }\end{array}$ & $\$ 1.31^{b}$ & 62.09 & 0.75 & $0.68^{b}$ & $0.42^{b}$ & 4.41 & 4.89 & 11.58 & $27.73^{b}$ \\
\hline
\end{tabular}

${ }^{a}$ Fruit based snacks included only snacks which were primarily fruit, such as purees, fruit chews and fruit buttons

${ }^{\mathrm{b}}$ Toddler product greater than 'regular' product, Premium fresh milk included branded (non-home brand) and A2 varieties

addition to higher mean sodium per $100 \mathrm{~g}$. Toddlerspecific yoghurts had lower mean protein, carbohydrate, total sugar, sodium, and calcium per $100 \mathrm{~g}$ than 'regular' yoghurts. Mean sodium levels per $100 \mathrm{~g}$ were nearly three-times lower in toddler rice-based snacks and close to six-times lower in dried fruit when compared to 'regular' products, although there is a high degree of variability in sodium levels in all toddler and regular foods, suggesting that consumer choice would be important in purchasing the lowest sodium items (Tables 2 and 3).
The average price of $1 \mathrm{~kg}$ of fresh fruit (average cost of banana, apple, pear, strawberries, raspberries, orange and watermelon at the time of analysis in September 2020 ) was $\$ 10.80$ whereas the average price per $\mathrm{kg}$ of toddler fruit-based snacks was $\$ 124.60$ (around 12 times more expensive). Similarly, the average price of $1 \mathrm{~kg}$ of dried fruit was $\$ 13.70$ and the average price of $1 \mathrm{~kg}$ of toddler dried fruit was $\$ 113.10$ (around 10 times more expensive). Yoghurt marketed specifically for toddlers was approximately $\$ 1.31$ more expensive per $100 \mathrm{~g}$ than regular yoghurt, equating to around $\$ 40$ per 


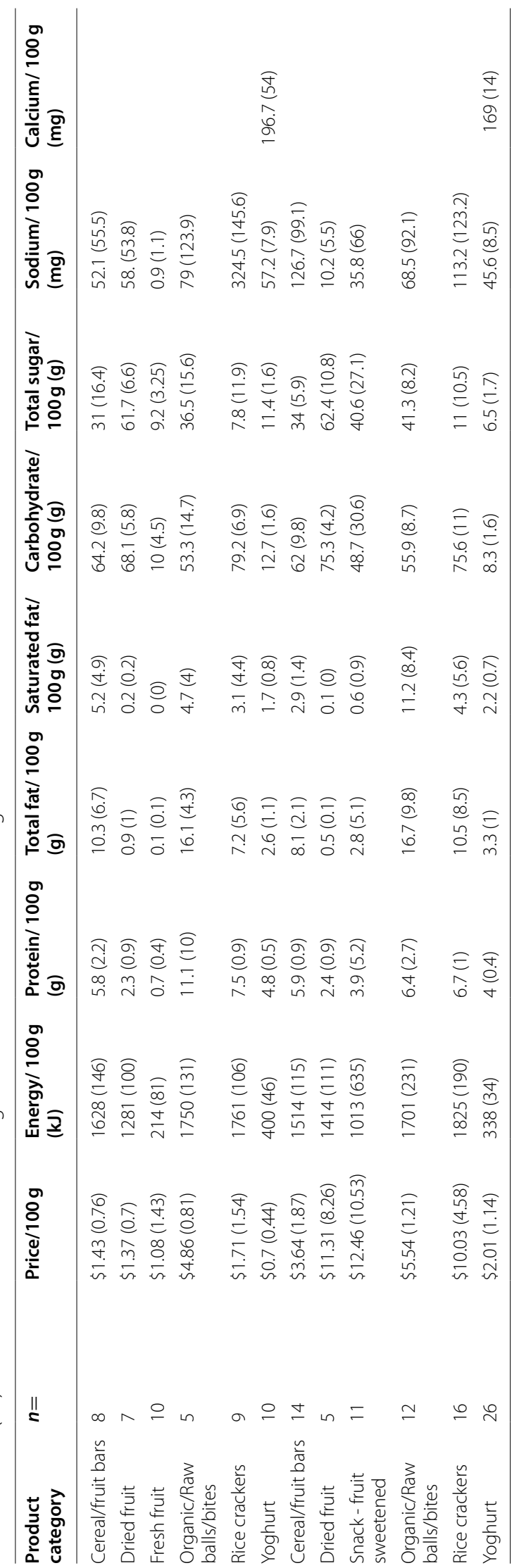


month, or $\$ 470$ per year if one $100 \mathrm{~g}$ serving was consumed daily.

\section{Discussion}

This study has demonstrated that toddler specific foods and milks cost more and do not represent value for money or good nutrition. There is limited research on consumption of toddler specific packaged foods and toddler milks in Australia and globally. The evidence that does exist includes two Australian studies on children aged 12-24 months [36, 37]. These studies reported that consumption of packaged foods is common with an average of $60 \%$ of toddlers consuming commercial sweet foods. The studies also reported $48 \%$ of toddlers consumed yoghurt (plain, flavoured and custard), 20\% consumed dried fruit, 23\% consumed sugar and sugary products and $35 \%$ consumed discretionary cereal products daily (based on $24 \mathrm{~h}$ recall and food-frequency questionnaires). Additional Australian research reported around $36 \%$ of toddlers consume toddler milk daily [16], and Australian national health survey data has also shown that close to $40 \%$ of toddlers aged 2-3 years consume yoghurt daily and close to $50 \%$ consume confectionery and cereal/nut/fruit/seed bars daily [38].

Putting the above consumption patterns into context with our results, it can be deduced that if a toddler were to consume the toddler-specific products daily, the cost would be much higher than if the 'regular' version of the product was purchased. This equates to a larger outlay of money (e.g. \$40 extra per month for one $100 \mathrm{~g}$ toddler-specific yoghurt daily, and $\$ 13$ more per month for one $200 \mathrm{~mL}$ serve of toddler milk), and with the cost of living increasing and wage growth stagnating [31], this impacts the household budget, and may become a social equity issue.

The same calculations can be made for all the toddlerspecific products, and all lead to the same conclusion: toddler-specific packaged foods cost significantly more than 'regular' foods. Looking at the nutrition provided from the toddler-specific foods, these vary greatly across the product categories. As an example, toddler-specific rice crackers had on average per $100 \mathrm{~g}$, lower mean protein, carbohydrate and sodium than the 'regular' rice crackers, but they also contained on average per $100 \mathrm{~g}$, higher mean total fat, saturated fat, total sugar and energy. So, while a toddler rice cracker may seem like it is healthier as it is lower in sodium, it is a trade-off, as it is higher in sugar. Low sodium 'regular' rice crackers (which are classified as core in the Australian Dietary Guidelines) are present in small numbers in the Australian retail market, and they do have lower levels of sodium and sugar per serve and per $100 \mathrm{~g}$ than even a toddlerspecific rice cracker, and may be the most suitable option for a rice-based snack for all ages, but would still not be recommended if they are UP.

Following on from this, if the example of toddler milk is examined in more detail, if a toddler milk was consumed daily, the toddler milks will ultimately provide more micronutrients than 'regular' milk due to fortification, but are an UPF. However, if the NIP nutrients mandated to be present are focused on, toddler milks are actually higher in carbohydrate, total sugar and energy per $100 \mathrm{~mL}$ than 'regular' milks, and the higher levels of these nutrients in the toddler milk are not required or recommended for healthy toddlers, as stated by the World Health Organization $[39,40]$ and the National Health and Medical Research Council [41].

A strength of this study is that the products included represent a relatively complete audit of all toddler-specific products on the market at the time and 'regular' foods were matched as closely as possible and are from the two leading supermarket outlets in Australia. A limitation of this study is that toddler-specific food consumption data is scarce however, we have included the most relevant data where possible. This indicates that consumption is considerable and that therefore there is a likely impact to food budgets if these products are chosen over regular foods. We are also not suggesting that the regular food alternatives are healthier choices than the toddler specific foods - indeed many are ULP and discretionary themselves. However, the point remains that a specific market has been created for toddler foods that demand a higher price premium.

\section{Conclusion}

To ensure that young children have a healthy start to life and become familiar with healthy foods (non UPF and drinks) from a young age, the message here is to buy regular family foods for better nutrition and cost savings, and avoid relying on toddler-specific foods and milks. Toddler milks and toddler-specific packaged foods are expensive distractions from what should actually be a simple, healthy diet. To support this, a strong regulatory approach to the marketing and nutrient content of toddler-specific food and milks is needed.

\section{Abbreviations}

UPF: Ultra-processed foods; UP: Ultra-processed.

\section{Acknowledgements}

Not applicable.

\section{Authors' contributions}

JM and JW conceptualised the study. $\mathrm{HB}$ and MC assisted with the initial study design. KB conducted all the analysis and wrote the results and co-wrote the methods section. JM wrote the introduction and implications for public health and co-wrote the methods section. All authors reviewed a final version of the manuscript. The author(s) read and approved the final manuscript. 


\section{Funding}

Research commissioned and funded by VicHealth.

\section{Availability of data and materials}

The datasets used and/or analysed during the current study are available from the corresponding author on reasonable request.

\section{Declarations}

Ethics approval and consent to participate

Not applicable.

\section{Consent for publication}

Not applicable.

\section{Competing interests}

Not applicable.

\section{Author details}

${ }^{1}$ Institute for Physical Activity and Nutrition (IPAN), School of Exercise and Nutrition Sciences, Deakin University, Geelong, Australia. ${ }^{2}$ Deakin Univer sity, Geelong, Australia. ${ }^{3}$ VACCHO, Collingwood, Australia. ${ }^{4}$ Victorian Department of Health, Melbourne, Australia. ${ }^{5}$ Institute for Physical Activity and Nutrition (IPAN), School of Exercise and Nutrition Sciences, Geelong, Australia.

\section{Received: 6 July 2021 Accepted: 8 February 2022}

\section{Published online: 25 February 2022}

\section{References}

1. Boesveldt $\mathrm{S}$, et al. The changing role of the senses in food choice and food intake across the lifespan. Food Qual Prefer. 2018:68:80-9.

2. Lundy $B$, et al. Food texture preferences in infants versus toddlers. Early Child Dev Care. 1998;146(1):69-85.

3. Nicklaus S. Children's acceptance of new foods at weaning. Role of practices of weaning and of food sensory properties. Appetite. 2011;57(3):812-5.

4. Birch L, Savage JS, Ventura A. Influences on the development of children's eating behaviours: from infancy to adolescence. Can J Diet Pract Res. 2007;68(1):s1-s56.

5. Birch LL, Fisher JO. Development of eating behaviors among children and adolescents. Pediatrics. 1998;101(3 II SUPPL):539-49.

6. Scaglioni $\mathrm{S}$, et al. Factors influencing children's eating behaviours. Nutrients. 2018;10(6):706.

7. Johnson SL. Developmental and environmental influences on young children's vegetable preferences and consumption. Adv Nutr. 2016;7(1):220S-31S

8. Khandpur $\mathrm{N}$, et al. Ultra-processed food consumption among the paediatric population: an overview and call to action from the European childhood obesity group. Ann Nutr Metab. 2020;76(2):109-13.

9. Baker $\mathrm{P}$, et al. First-food systems transformations and the ultra-processing of infant and young child diets: the determinants, dynamics and consequences of the global rise in commercial milk formula consumption. Matern Child Nutr. 2020;17:e13097.

10. Moubarac JC, et al. Consumption of ultra-processed foods and likely impact on human health. Evidence from Canada. Public Health Nutr. 2013;16(12):2240-8.

11. Crovetto MM, et al. Household availability of ready-to-consume food and drink products in Chile: impact on nutritional quality of the diet. Rev Med Chil. 2014;142(7):850-8.

12. Juul F, Hemmingsson E. Trends in consumption of ultra-processed foods and obesity in Sweden between 1960 and 2010. Public Health Nutr. 2015;18(17):3096-107.

13. Solberg SL, Terragni L, Granheim SI. Ultra-processed food purchases in Norway: a quantitative study on a representative sample of food retailers. Public Health Nutr. 2016;19(11):1990-2001

14. Zobel EH, et al. Global changes in food supply and the obesity epidemic. Curr Obes Rep. 2016;5(4):449-55.
15. Coxon C, et al. Sources and determinants of discretionary food intake in a cohort of Australian children aged 12-14 months. Int J Environ Res Public Health. 2019;17(1):80

16. Willcox JC, et al. Commercial growing up milks: usage frequency and associated child and demographic factors across four Asia Pacific countries. J Hum Nutr Diet. 2020;34:524-33.

17. Baker P, et al. Global trends and patterns of commercial milk-based formula sales: is an unprecedented infant and young child feeding transition underway? Public Health Nutr. 2016;19(14):2540-50.

18. Baker $P$, et al. Globalization, first-foods systems transformations and corporate power: a synthesis of literature and data on the market and political practices of the transnational baby food industry. Glob Health. 2021;17(1):58

19. Lee AJ, et al. Testing the price and affordability of healthy and current (unhealthy) diets and the potential impacts of policy change in Australia. BMC Public Health. 2016:16(1):315.

20. Davis GC, You W. Not enough money or not enough time to satisfy the Thrifty Food Plan? A cost difference approach for estimating a moneytime threshold. Food Policy. 2011;36(2):101-7.

21. Devia $G$, et al. References to home-made and natural foods on the labels of ultra-processed products increase healthfulness perception and purchase intention: insights for policy making. Food Qual Prefer. 2021;88:104110.

22. Koo Y-C, Chang J-S, Chen YC. Food claims and nutrition facts of commercial infant foods. PLoS One. 2018;13(2):1-13.

23. Pulker CE, Scott JA, Pollard CM. Ultra-processed family foods in Australia: nutrition claims, health claims and marketing techniques. Public Health Nutr. 2017;21(1):38-48.

24. Charlton EL, et al. Supermarkets and unhealthy food marketing: an international comparison of the content of supermarket catalogues/circulars. Prev Med. 2015:81(Supplement C):168-73.

25. Hickey K, et al. Overbranded, underprotected: how industry selfregulation is failing to protect children from unhealthy food marketing. Melbourne: Obesity Policy Coalition; 2018.

26. Brownbill AL, Miller CL, Braunack-Mayer AJ. The marketing of sugarsweetened beverages to young people on Facebook. Aust N Z J Public Health. 2018;42(4):354-60.

27. Greisen G, Grossman ER, Siegel M, Sager M. Public health and the four P's of marketing: alcohol as a fundamental example. J Law Med Ethics. 2019:47:51-4.

28. Boak $R$, et al. Choosing foods for infants: a qualitative study of the factors that influence mothers. Child Care Health Dev. 2016:42(3):359-69.

29. Tilgner A, et al. What drives parents to buy toddler milk? Ernaehrungs Umschau Int. 2013;60(7):116-23.

30. Hughes J, Berry J, Brown L. Parental motivations and beliefs regarding purchase and use of toddler specific convenience foods in high and low-income Massachusetts towns. J Acad Nutr Diet. 2016;116(9, Supplement):A27.

31. McKay FH, et al. The prevalence, severity and experience of food insecurity in Australia: an investigation of food aid use. Health Soc Care Community. 2020;28(6):2399-407.

32. Marchese $L$, et al. Ultra-processed food consumption, socio-demographics and diet quality in Australian adults. Public Health Nutr. 2022;25(1):1-11.

33. Jun S, et al. Usual nutrient intakes from the diets of US children by WIC participation and income: findings from the feeding infants and toddlers study (FITS) 2016. J Nutr. 2018:148(9s):1567s-74s.

34. Clemons, R. How much of the grocery market share does each supermarket have?. Supermarket market share. 2018. Available from: https://www. choice.com.au/shopping/everyday-shopping/supermarkets/articles/ accessible-text-files/supermarket-market-share. Cited 2019 June.

35. McCann JR, et al. Nutrition and packaging characteristics of toddler foods and milks in Australia. Public Health Nutr. 2020;24(5):1153-65.

36. Campbell KJ, et al. Early life protein intake: food sources, correlates, and tracking across the first 5 years of life. J Acad Nutr Diet. 2017;117(8):11881197.e1.

37. Bell LK, et al. Dietary patterns and risk of obesity and early childhood caries in Australian toddlers: findings from an Australian cohort study. Nutrients. 2019;11(11):2828. 
38. Australian Bureau of Statistics. Australian health survey: nutrition first results - foods and nutrients, 2011-12. Canberra; Australian Bureau of Statistics. 2014. https://doi.org/10.1186/s12937-022-00765-1.

39. World Health Organization. Evaluating implementation of the WHO set of recommendations on the marketing of foods and non-alcoholic beverages to children, in Progress, challenges and guidance for next steps in the WHO European region. Copenhagen: World Health Organization; 2018.

40. World Health Organization. Infant and young child feeding. Fact sheets - detail. 2018. Available from: https://www.who.int/news-room/factsheets/detail/infant-and-young-child-feeding. Cited 2019 July.

41. National Health and Medical Research Council. Infant feeding guidelines. 2012.

\section{Publisher's Note}

Springer Nature remains neutral with regard to jurisdictional claims in published maps and institutional affiliations.

- fast, convenient online submission

- thorough peer review by experienced researchers in your field

- rapid publication on acceptance

- support for research data, including large and complex data types

- gold Open Access which fosters wider collaboration and increased citations

- maximum visibility for your research: over $100 \mathrm{M}$ website views per year

At BMC, research is always in progress.

Learn more biomedcentral.com/submissions 